\title{
11
}

\section{Is It Strategic to Attract the Service Activities of Multinational Firms? Some Empirical Evidence}

\author{
Fabrice Defever
}

\subsection{Introduction}

It is well known that many governments provide incentives to attract foreign firms. Barba Navaretti and Venables (2004) offer several examples of such proactive behavior; the U.S. state of Alabama and the Portuguese government, respectively, granted subsidies equivalent to $\$ 160,000$ and $\$ 250,000$ per employee to a foreign car producer. These incentives take many forms, including tax cuts, employment, and capital grants. ${ }^{1}$

However, both academics and policymakers seem to have neglected the possibility of attracting service functions associated with production activity. Indeed, the fragmentation of the production process of multinational firms cannot be restricted to the production side. Krugman (1995) considers that the international value chain decomposition is one of the four major aspects of the modern international trade. He calls this phenomenon "slicing the value chain" and includes in his definition a large number of service activities. As noted by the World Investment Report (2001, pp. 72-82): "Historically critical corporate functions like design, $\mathrm{R} \& \mathrm{D}$, strategic and financial management or the procurement of core inputs have been kept at headquarters. It is possible in theory, however, for TNCs to place each function in a different location to take advantage of different characteristics and thus optimize efficiency for the company as a whole. There is growing evidence that this is taking place."

For policymakers, the attraction of service activities, like headquarters or research and development centers, could be not only an indirect way to strengthen human capital formation and technological capacities, but could also lead to the subsequent location of other parts of the multinational firms' value chain. 
Policy instruments are obviously not the only factor that can influence the location choice of multinational firms. Previous investments have also been considered by location theory as essential. For instance, when vertical relationships are strong enough, multinational firms colocate their activities within the same country. Head, Ries, and Swenson (1995) investigated possible supply relationships or technological spillovers between members of the same industrial keiretsu, and Smith and Florida (1994) considered relationships between two distinct parts of the production process. These authors study the investments of Japanese auto-related-parts suppliers and show that they tend to locate near Japanese assembly plants. More recently, Chung and Song (2004) showed that prior investments of Japanese electronics firms in the United States strongly influenced the location choice of their subsequent investments.

Co-location could be an important factor when considering service functions. As noted by Markusen (2005), service activities are likely to be internalized by the firm rather than bought and sold on arm'slength markets, and there may be crucial complementarities among different elements of the production chain. Fragmentation of the production process may generate significant coordination costs, which could be lessened by the co-location of their complementary activities within the same country.

Here I study pre- and postproduction service activities, which have been widely neglected by location theory. Following Defever (2006), I use a unique data set collected by the consulting group Ernst \& Young. Data of almost 11,000 location choices were collected at the individual firm level over the period 1997-2002. This data set identifies the location of production plants, as well as the location of several types of service functions, including headquarters and research and development (R\&D) centers, logistics, and sales and marketing activities. I consider both fifteen old European Union countries (EU-15) and eight Central and Eastern European countries (CEE-8) as possible location choices.

As a result of the information provided by this data set, I roughly estimate the number of jobs created by multinational firms in both western and eastern Europe during this period in order to underline the importance, in terms of jobs created by multinational firms, of the service activities, especially in western European countries.

Then I empirically analyze the within-firm co-locations between different stages of the value chain. I show that vertical linkages between 
functions push firms to concentrate affiliate activities within the same country. It is found that service activities are likely to be located in countries where the firm has previously set up a production plant. In addition, $R \& D$ seems to exert a very strong, attractive effect on production plant location. Therefore, the proactive attraction of the R\&D centers may trigger the location of production plants.

The remainder of the chapter is organized as follows: Section 11.2 presents the database and proposes some empirical evidence on the number of jobs created by the multinational firms. Section 10.3 discusses the econometric model. Section 10.4 explains the dependent and independent variables used. Section 10.5 presents the econometrics results. Section 10.6 discusses the implications for policymakers.

\subsection{Data}

\subsubsection{Description of the Database}

Empirical evidence on the number of jobs created by multinational firms and on the co-location of multinational firms' activities will be evaluated using a database of multinational firms' location in Europe over the period 1997-2002, computing more than 11,182 projects. $^{2}$

This EIM (European Investment Monitor) database, developed by the consulting group Ernst \& Young, identifies the project-based foreign inward investment announcements that are new, expanding, or co-located in an international context. ${ }^{3}$ The main sources of information are newspapers, financial information providers (such as Reuters), and national investment agencies (such as Invest in France Agency). When the consulting group discovers a new project, it tracks it in order to determine the exact location, at the city level. Projects included in the database have to comply with several criteria to be considered an international investment with mobility. The database excludes acquisitions, license agreements, and joint ventures (except in the case where these operations lead to an extension or a new establishment creation). It also excludes retail, hotel and leisure facilities, fixed infrastructures, extraction facilities, and portfolio investments. There is no minimum investment size criterion, but the number of investments with fewer than ten job creation projects is very low.

The investment projects data are at an individual level and provide investments in Europe by European and non-European firms, except for investments in the home country. The database includes the name 
of the firm, the parent company name, the name and the origin country of the parent company, the country of location, and the sector. There are forty-nine manufacturing and nonmanufacturing sectors in the NACE classification, ${ }^{4}$ with subsectors in the automotive, electric and electronic, and chemical sectors. It also includes the function of each investment: unit of production and different service activities, such as headquarters, research and development centers, logistics, or sales and marketing offices.

\subsubsection{The Five Functions Considered}

I consider the five following functions: production plant, headquarters, R\&D centers, logistics, and sales and marketing offices. Other functions are available, ${ }^{5}$ but I could not use them due to the limited number of investments.

The headquarters function corresponds to administration, management, and accounting activities localized internationally. It includes decision centers, but the data do not allow us to know exactly their importance in the global decision process, and none correspond to the principal decision center. In fact, investments realized in the home country are not considered in the data set. Therefore, most of these centers correspond to European or regional headquarters (e.g., north of Europe) or are intended for the network organization only at a national level.

Research and development centers can be related to fundamental scientific research and to applied development directly linked to the production process. Data do not allow us to distinguish between centers dedicated to the development of new products and those to the adaptation to the local market of existing products.

Production plants correspond to the whole entity related to the physical production of goods.

The logistics function refers to all entities linked to goods transport, including warehousing (e.g., regional goods distribution). They can be internal to the firm or external logistics, for distributing to customers or suppliers. Logistics can also be viewed as acting as an intermediary between component production and assembly.

The sales and marketing offices include both wholesale trade and business representative offices. Despite the fact that they are not limited by size, the database appears to cover only the biggest investments. 
Table 11.1

Total jobs created by function

\begin{tabular}{lclllr}
\hline & $\begin{array}{l}\text { Number } \\
\text { of } \\
\text { projects }\end{array}$ & $\begin{array}{l}\text { Average } \\
\text { jobs } \\
\text { created } \\
\text { by project }\end{array}$ & $\begin{array}{l}\text { Job } \\
\text { creation } \\
\text { observed }\end{array}$ & $\begin{array}{l}\text { Jobs } \\
\text { estimated }\end{array}$ & $\begin{array}{r}\text { Total job } \\
\text { creation }\end{array}$ \\
\hline Headquarters & 859 & 101 & 54,356 & 34,542 & 88,898 \\
R\&D centers & 1,002 & 130 & 98,003 & 39,247 & 137,250 \\
Production & & & & & \\
In EU-15 countries & 3,912 & 159 & 438,944 & 220,151 & 659,095 \\
In CEE-8 countries & 1,304 & 316 & 280,525 & 156,736 & 437,261 \\
Logistics & 958 & 110 & 62,648 & 45,067 & 107,715 \\
Sales and & 3,148 & 39 & 72,133 & 52,213 & 124,346 \\
marketing & 11,182 & & $1,006,607$ & 547,957 & $1,554,565$ \\
Total & & & & & \\
\hline
\end{tabular}

Note: New creations and extensions in twenty-three countries (EU-15 and CEE-8) and on the five functions during the period 1997-2002. European and non-European firms.

\subsubsection{Job Creation by Multinational Firms}

Before turning to the econometric estimation on the co-location between activities, I present some descriptive statistics on the importance of the jobs created in service and production activities by multinational firms. The database information also includes the number of jobs created in each project. Unfortunately, this information is available for only around 65 percent of the projects (see the "Job Creation Observed" in table 11.1). To complete the information for the 35 percent of the projects with the missing value, I consider the specific project size of activities and then calculate an average number of job creation for each function, as presented in the third column of table 11.1. In the case of the production function, I also distinguish between the project size depending on if it is realized in western or eastern Europe. In fact, average job creation for production plants realized in central Europe appears to be at least twice as large as in the West (on average, 159 jobs created by production plants in the EU-15 and 316 jobs created in the CEE-8). This allows us to complete missing data for projects that do not have information on the number of jobs created (see the "Jobs Estimated" column in table 11.1). This permits us to estimate the total number of jobs created by multinational firms during the period 1997-2002 (the final column of table 11.1). Considering the individual data, the correlation between the reported number of jobs 
Jobs created per capita in headquarters

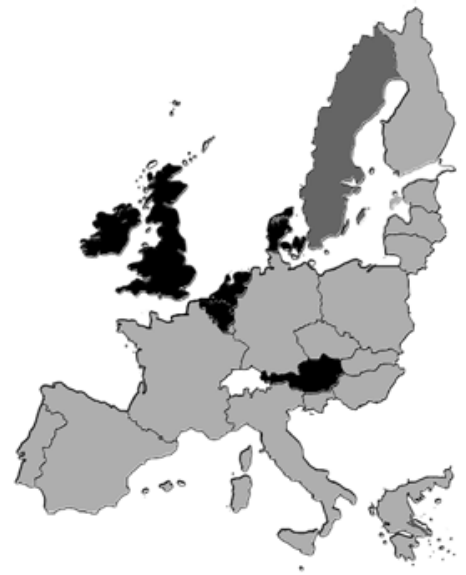

Jobs created per capita in production units

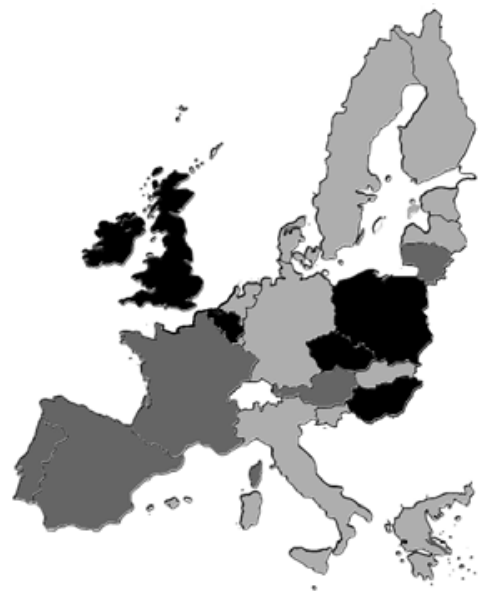

Jobs created per capita in sales \& marketing

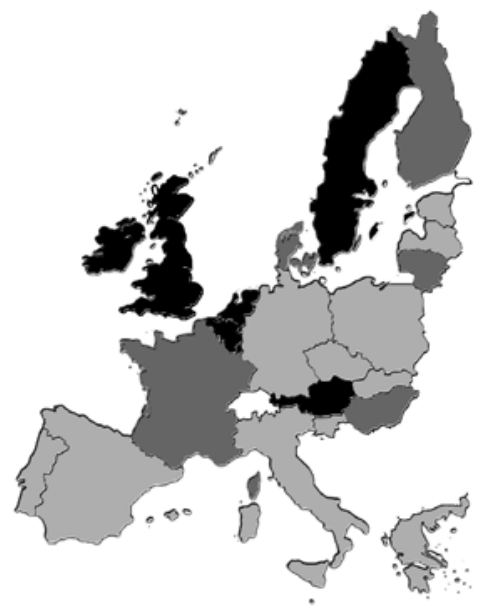

Jobs created per capita in $R \& D$ centers

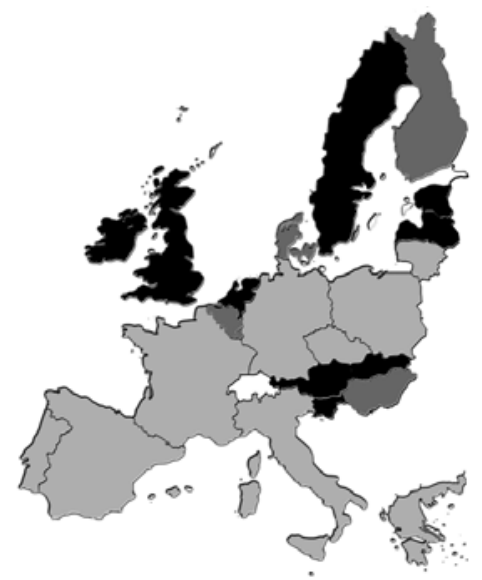

Jobs created per capita in logistics plants

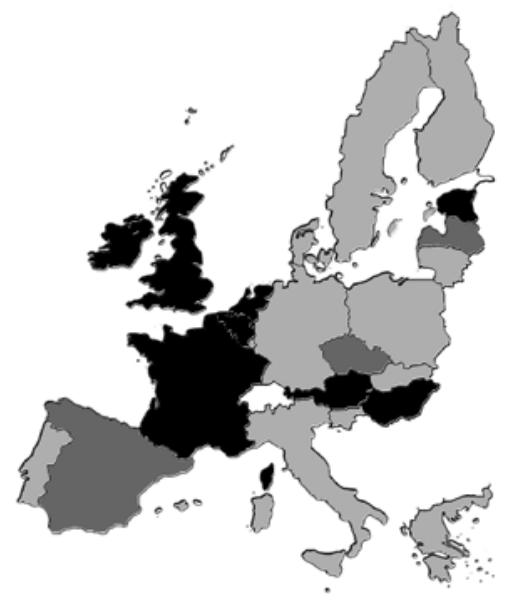

Number of jobs created 30 percent above the European average

$\square$ Number of jobs created between 30 percent and -30 percent around the European average

$\square$ Number of jobs created 30 percent below the European average 
Table 11.2

Structure of estimated job creation in EU-15 and CEE-8 countries

\begin{tabular}{lrrr}
\hline Function & \multicolumn{1}{c}{ EU-15 } & \multicolumn{1}{c}{ CEE-8 } & \multicolumn{1}{c}{ Total } \\
\hline Service activities & 421,812 & 36,397 & 458,209 \\
Production & 659,095 & 437,261 & $1,096,356$ \\
Total & $1,080,907$ & 473,658 & $1,554,565$ \\
\hline
\end{tabular}

Note: New creations and extensions in twenty-three countries (EU-15 and CEE-8) and on the five functions during the period 1997-2002. Manufacturing and nonmanufacturing sectors. European and non-European firms.

created and the number of jobs that would be estimated using this estimation is around 22 percent. This indicates the huge heterogeneity of the data not captured by this simple methodology. ${ }^{6}$ This approach is arguably imperfect, but it does allow me to provide some descriptive statistics at an aggregate level not available from other sources. At the microlevel, this estimation is far from being precise enough to be used as a dependent variable.

At an aggregate level, multinational firms located in the twentythree countries 11,182 investments during the period 1997-2002. My estimation leads to an approximation of more than 1.5 million jobs created during this period. ${ }^{7}$ Figure 11.1 shows maps of the geographical distribution of the five functions (headquarters, R\&D, production, logistics, and sales and marketing offices) during the period 1997 to 2002. To correct for size, I consider the number of jobs created (using my estimates) for each function divided by the countries' population. In some countries, such as the United Kingdom and Ireland, the number of jobs created is 30 percent above the European average for all the functions relative to their population size. At the opposite end, in Italy and Greece, again relative to their population size, the number of jobs created is 30 percent below the European average for a given population for five activities.

Table 11.2 shows that around 1 million of these jobs have been created in production activities, with one-third being realized in service activities. Notice that production represents 90 percent of the job created by the MNF in Central and Eastern Europe (CEE-8) countries and

Figure 11.1

Number of jobs created by function related to the countries' population Note: New creations and extensions of European and non-European firms in the manufacturing sector in twenty-three countries (EU-15 and CEE-8) during the period 19972002. 
only 60 percent in the EU-15 countries. These statistics seem to demonstrate that governments should pay more attention to service activities, especially in western European countries.

\subsection{Econometric Model}

In order to consider the impact of vertical linkages on location choice, we use individual firm location choices over a set of twenty-three European countries. The most commonly used econometric modeling technique for this type of problem is the conditional logit model (CLM) proposed by McFadden. Each location decision is a discrete choice made among several alternatives.

Although the real underlying profit yielded by alternative locations cannot be observed, one does observe the actual choice of each firm $l$ and the characteristics of the alternative locations. Suppose $R=$ $\{1, \ldots, r, \ldots, o\}$ is the set of possible location countries.

There are two types of determinants of location: country characteristics and previous location of plants defined at the individual firm level. In order to capture the attractiveness of location $r$ to the representative investor (common to all investors independent), we introduce a fixed effect to capture country characteristics for each location, noted $\theta_{r}{ }^{8}$ So each location offers a profit of $\pi_{l r}$ to the firm $l$ such that

$\pi_{l r}=\theta_{r}+\beta X_{l r}+\varepsilon_{l r}$,

where $X_{l r}$ indicates previous investments realized by the firm $l$ in each location choice $r, \beta$ a vector of coefficients to be estimated by maximum likelihood procedures, and $\varepsilon_{l r}$ the unobservable advantage of the location $r$. The firm $l$ will choose $r$ if the profit at this location is higher than those obtained in any other alternative location. Hence, the probability of choosing $r$ is

$P_{l r} \equiv \operatorname{Prob}\left(\pi_{l r}>\pi_{l k}\right)=\operatorname{Prob}\left(\varepsilon_{l k}<\varepsilon_{l r}+\theta_{r}-\theta_{k}+\beta\left(X_{l r}-X_{l k}\right)\right), \quad \forall k \neq r$.

The crucial assumption of the CLM is that the error terms are independently and identically distributed according to a type I extreme value distribution. It leads to the simple probability of choosing location $r$ :

$P_{l r}=\frac{e^{\theta_{r}+\beta X_{l r}}}{\sum_{i=1}^{o} e^{\theta_{i}+\beta X_{l i}}}$. 
One of the main assumptions of CLM is to do with the independence of irrelevant alternatives (IIA), which implies that the relative probability of choosing one country is independent of the destination choice set: working on a subsample or on the whole sample should produce the same results (except, of course, the loss of information in the omitted decision). But unobserved characteristics of the choosers and unobserved correlations across element choices can generate a form of IIA assumption violation (Train 2003). The introduction of country fixed effects removes some forms of the IIA violation. Due to a limited period of time of our dependent variable, this methodology does not permit us to introduce country characteristics variables. Therefore, we will consider variables defined not only at the country level but also at the firm level. Also, we should be careful that unobserved characteristics of the choosers do not make some choices closer substitutes than others. To test the robustness of our results, we would have to consider different subsamples.

\subsection{Dependent and Independent Variables}

\subsubsection{Construction of the Dependent Variable}

We consider as a possible location choice twenty-three countries of the enlarged Europe. In order to study the possible co-location of all functions, including production, we consider only the manufacturing sector and exclude other sectors (essentially service sectors). ${ }^{9}$ In addition, we are able to distinguish projects between actual creations (also known as greenfield) and extensions (e.g., brownfield). This latter category is not directly linked to the location choice determinants. Consequently, we use only actual creations for the construction of the dependent variable.

Considering only manufacturing sectors in the twenty-three European countries, the creation of greenfields represent 5,138 investments. One would expect that the fragmentation of the production process drives the different parts of the value chain to be located in accordance with countries' characteristics. From table 11.3, we can observe that production investments in the CEE- 8 countries represent 81 percent compared to 48 percent in the EU-15.

During the period 1997-2002, of the 2,858 parent companies acting in manufacturing sectors that created new establishments in the twenty-three countries, 2,496 created new establishments for only one function. Of the rest of the sample, 240 firms realized investments 
Table 11.3

Structure of new investments in manufacturing sectors in EU-15 and CEE-8 countries

\begin{tabular}{lrrr}
\hline Function & EU-15 & CEE-8 & Total \\
\hline Headquarters & 327 & 9 & 336 \\
R\&D & 572 & 47 & 619 \\
Production & 1,841 & 1,032 & 2,873 \\
Logistics & 408 & 83 & 491 \\
Sales and marketing & 712 & 107 & 819 \\
Total number of investments & 3,860 & 1,278 & 5,138 \\
\hline
\end{tabular}

Note: New creations in the manufacturing sectors in twenty-three countries (EU-15 and CEE-8) and on the five functions during the period 1997-2002. European and nonEuropean firms.

in two types of activities, 75 in three, 24 in four, and 23 in all five functions studied. Some firms realized an impressive number of investments. For example Ford Motor Co. had thirty-seven new establishment announcements during the period 1997-2002. ${ }^{10}$

\subsubsection{The Independent Variables}

\section{Co-location Variables}

We introduce co-location variables between functions in order to consider national vertical linkages between stages of the value chain. In fact, these within-firm linkages are likely to encourage multinational firms to co-locate functions to save coordination costs. In this study, we consider only national co-location. To do this, we build five colocation variables-one for each function $f$. We build the historic establishment for each parent company and for each function in each country $r$. To do that, we take into account all the projects of the sample-greenfield and brownfield. More precisely, we include all the establishment extensions for each firm (which represent about onethird of the database projects) realized during the period 1997-2002 and that were not created by the firm during this period. ${ }^{11}$ This allows us to consider these investments as anterior investments, to which we will add the new establishment creations realized by the firm during the years before the specific investment studied. In order to study precisely the history of location in a specific site, we would have to consider for each function only one possible investment for each parent company and for each city. ${ }^{12}$ Finally, we consider that the variable takes the value 1 if the function $f$ has been previously implanted in 
Table 11.4

Dependent and independent variable descriptions

\begin{tabular}{|c|c|c|}
\hline Variables & Definition & Year \\
\hline Y & $\begin{array}{l}\text { Location choices among } 23 \text { European countries } \\
\text { of European and non-European firms from } \\
\text { manufacturing sectors (greenfield only) }\end{array}$ & 1997-2002 \\
\hline \multicolumn{3}{|l|}{ Co-location variables } \\
\hline $\begin{array}{l}\text { Headquarters } \\
\text { co-location }\end{array}$ & $\begin{array}{l}1 \text { if a headquarters has been located in the past } \\
\text { in country } r \text { and } 0 \text { otherwise (greenfield and } \\
\text { brownfield) }\end{array}$ & 1997-2002 \\
\hline R\&D co-location & $\begin{array}{l}1 \text { if a R\&D function } f \text { has been located in the } \\
\text { past in country } r \text { and } 0 \text { otherwise (greenfield } \\
\text { and brownfield) }\end{array}$ & 1997-2002 \\
\hline Production co-location & $\begin{array}{l}1 \text { if a production plant has been located in the } \\
\text { past in country } r \text { and } 0 \text { otherwise (greenfield } \\
\text { and brownfield) }\end{array}$ & 1997-2002 \\
\hline Logistics co-location & $\begin{array}{l}1 \text { if a logistics activity has been located in the } \\
\text { past in country } r \text { and } 0 \text { otherwise ( greenfield } \\
\text { and brownfield) }\end{array}$ & 1997-2002 \\
\hline $\begin{array}{l}\text { Sales and marketing } \\
\text { co-location }\end{array}$ & $\begin{array}{l}1 \text { if a sales activity has been located in the past } \\
\text { in country } r \text { and } 0 \text { otherwise (greenfield and } \\
\text { brownfield) }\end{array}$ & 1997-2002 \\
\hline
\end{tabular}

the country by one of the affiliates of the parent company and 0 otherwise. $^{13}$ This will allow us to consider the within-firm co-location between functions. Table 11.4 summarizes the variables that will be used.

\subsection{Econometric Test}

Considering the location choice of new investments in the manufacturing sector, this section introduces co-location variables between functions within the same parent company in a specific country. We do not include the diagonal of the subdivided network variables (for which setting up a function $f$ would have been explained by the presence of the same function by other affiliates). In fact, we are more interested in vertical linkages than within-function co-location. Conditional logit estimation with country fixed effect (table 11.5) leads to two main results: (1) within-firm vertical linkages tend to locate services activities in the same country as production plants and (2) R\&D centers and production plants seem to be strongly attracted by each other. ${ }^{14}$

The four service functions surrounding production are all attracted by the production location. $R \& D$ and logistics have high and significant 
Table 11.5

Co-location between functions in the east and west of Europe

\begin{tabular}{lccccc}
\hline & \multicolumn{3}{l}{ Dependent variable: Location choice } & & \\
\cline { 2 - 6 } Variables & $\begin{array}{l}\text { Head- } \\
\text { quarters }\end{array}$ & R\&D & Production & Logistics & $\begin{array}{c}\text { Sales and } \\
\text { marketing }\end{array}$ \\
\hline Headquarters & & 0.16 & -0.09 & -0.06 & -0.27 \\
co-location & & $(0.22)$ & $(0.16)$ & $(0.36)$ & $(0.27)$ \\
R\&D co-location & 0.05 & & $0.93^{\mathrm{a}}$ & 0.11 & -0.04 \\
& $(0.28)$ & & $(0.11)$ & $(0.29)$ & $(0.22)$ \\
Production co-location & $0.47^{\mathrm{b}}$ & $0.74^{\mathrm{a}}$ & & $0.78^{\mathrm{a}}$ & 0.07 \\
& $(0.22)$ & $(0.13)$ & & $(0.16)$ & $(0.16)$ \\
Logistics co-location & -0.54 & 0.19 & $0.27^{\mathrm{c}}$ & & -0.08 \\
& $(0.40)$ & $(0.24)$ & $(0.14)$ & & $(0.28)$ \\
Sales and marketing & 0.08 & 0.01 & -0.25 & 0.44 & \\
co-location & $(0.35)$ & $(0.20)$ & $(0.17)$ & $(0.30)$ & \\
Country fixed effect & Yes & Yes & Yes & Yes & Yes \\
Number of choosers & 336 & 619 & 2,873 & 491 & 819 \\
Number of choices & 23 & 23 & 23 & 23 & 23 \\
Log likelihood & -684 & $-1,430$ & $-7,425$ & $-1,180$ & $-2,032$ \\
\hline
\end{tabular}

Note: Standard errors in parentheses: ${ }^{\mathrm{a}},{ }^{\mathrm{b}}$, and ${ }^{\mathrm{c}}$ represent respectively 1 percent, 5 percent, and 10 percent significance levels. Dependent variable: Location choice in 23 countries (EU-15 and CCE-8) and of the five functions during the period 1997-2002. New creations of European and non-European firms in the manufacturing sector.

coefficients associated with production co-location variables, while headquarters is only weakly significant and sales and marketing is not significant. For example, of the 392 firms that had already established at least one production plant and decided to locate a new R\&D facility, 211 chose the country of a previous production plant location.

The second important result of the introduction of vertical linkage variables is the co-location between R\&D and production plants. In fact, those functions are highly attracted to each other, and the strong vertical linkages between activities are likely to lead to strong colocation between these two activities. R\&D is the only service activity that has a significant attractive effect on production. More specifically, with a 1 percent significant coefficient of 0.93 , a firm is more likely to locate its production plant in a country in which it already has an $R \& D$ center located. So we can clearly identify a co-location aspect between R\&D and production, which could be driven by R\&D (R\&D co-location variable has the highest coefficient). In terms of number of projects, of the 2,873 production location choices, 153 of these facilities 
were established in a country where the parent company had previously located a R\&D center. This low number is due to the fact only a small number of firms decide to locate $R \& D$ facilities abroad. More precisely, of the firms that decide to realize an investment in production activity, only 503 firms previously had an R\&D center located in one of the 23 countries considered and 344 when considering only the EU-15 countries. Considering the 23 countries, around 30 percent (153 firms of 503) chose the R\&D host country to locate their production plant. When considering only the EU-15 countries, these firms represent around 38 percent (132 firms of 344). These statistics permit us to understand the high coefficient of the R\&D co-location (see table 11.5).

The inclusion of country dummy variables allows the use of a conditional logit specification in the presence of some forms of IIA violation. In order to consider the robustness of these results using a country fixed-effect setup, I reestimated the model using a variety of subsamples, where each subsample is chosen to remove a potential violation of the independence assumption. Notably I run the econometric model considering (1) only EU-15 and (2) all countries but excluding both France and the United Kingdom, which together account for 35 percent of new investments in manufacturing sectors. In both cases, the coefficients on the parameters of primary interest remain remarkably stable. $^{15}$

\subsection{Implications for Policymakers}

Some policy implications can be taken from this analysis. First, it provides some statistics demonstrating the importance of multinational firms' investments and job creation in service activities. Services account for one-third of all jobs created by multinational firms in the enlarged Europe. Taking into account the EU-15 countries only, this ratio increases to 39 percent. Financial incentives are largely devoted to production plant attraction, but when my estimations are considered, it seems reasonable to pay more attention to service activities also, specifically in modern service economies.

I empirically analyzed the co-location of the different stages of the value chain between affiliates of multinational firms. Using a country fixed-effects conditional logit, I showed that firms are likely to locate several service activities in countries where they have already located a production plant. The location of a production plant leads to subsequent investment in service activities. 
This work also highlights some strategic aspects of location for policy makers. Notably, some functions could have strategic aspects for both multinational firms and host countries. Attracting an R\&D center largely increases the probability of the firm's choosing the same country for locating its production plant. In addition, the results seem to demonstrate that unlike $R \& D$ centers, headquarters do not have any attractive effect on the affiliates' production plant location choice, which could revise policy orientation through privilege subsidies to R\&D. ${ }^{16}$

Of course, this policy advice mainly applies to the attraction of the largest firms with multiple locations. In addition, only a small number of firms decide to locate R\&D facilities abroad. This limits the policy action to a limited, but well-defined, number of projects. Finally, because the time dimension of the data set is limited, prediction of the co-location of activities is probably more applicable to firms expanding their location rapidly in Europe during a short period of time. ${ }^{17}$ Firms that decide to locate a few pieces of their value chain simultaneously are possibly more likely to choose a location for an activity based on their knowledge of the future location of other activities.

\section{Notes}

The study of the quality of the database was carried out at the Invest in France Agency under the supervision of Fabrice Hatem and Edouard Mathieu. I thank them for their help. I am very grateful to the consulting group Ernst \& Young and, more specifically, to Barry Bright and Mark Hughes. Many thanks to Rodolphe Desbodes, Fabian Gouret, and the participants at the CESifo Summer Institute Workshop, "Recent Developments in International Trade: Globalization and the Multinational Enterprise," Venice International University, San Servolo, July 18-19, 2005. Three referees provided helpful comments, for which I am particularly grateful. The observations and viewpoints expressed are solely my responsibility.

1. There are many arguments against government incentives. Notably it can be argued that they distort competition or are an inefficient way to attract multinational firms, especially when they give rise to costly international bidding. I will not discuss these aspects. Instead, I will consider the need for governments to attract FDI as given. Subsequent literature has tended to find that corporate taxes and other incentives have a significant effect on the location of multinational firms, but the evidence is far from conclusive and still largely disputed. See notably Head, Ries, and Swenson (1999) and Devereux and Griffith (1998).

2. The complete database includes 13,109 projects when one considers all countries and all functions available. I will limit the descriptive statistics to five functions and twentythree countries: the fifteen "old" European Union countries (EU-15) and the eight central and eastern European countries (CEE-8) that joined the European Union in 2004, but excluding Malta and Cyprus. Other countries were available, including Russia and Tur- 
key, but they represent a small number of investments. The five functions considered are described in the next section.

3. See www.eyeim.com.

4. Classification of Economic Activities in the European Community.

5. Contact center, education and training, Internet data center, testing and servicing, and service center. These functions represent 770 projects.

6. Also considering country-specific project size could have strongly increased the correlation (at least by construction), but some countries account for a very low number of investments in service activities. Using the same data set, Hatem and Defever (2003) approximated the number of job created by multinational firms for the period 1998-2002 using a much more complex methodology. They calculated the average number of jobs created depending on the function of the project, the sector of the firms (for the production activity only), and the type of the project (creation or expansion of establishment). They also calculated capital intensity by sector (or by function in the case of service activities) and used the investment amount of the project, when either was available, to approximate the size of the project in order to complete the job creation information. They considered three groups of countries (east, northwest, and southwest) that could differ in terms of project size. At an aggregate level, their results are comparable to ours.

7. Because there is no other comparable data set, it is difficult to see how exhaustive the data set is. The Invest in France Agency (AFII) is providing a similar data set, Bilan France, but only for France. This organization is part of the French Ministry of the Economy, and the quality and the exhaustiveness of the data set seem higher. It includes the number of jobs created for each operation with a minimum size criterion of ten jobs. For the period 1997-2002, the Bilan France includes 2,813 projects leading to a total of more than 169,000 new jobs created. The EIM data set has no minimum of investment size criterion, but the number of investments with fewer than ten jobs created is very low. For the period 1997-2002, the EIM data set includes 1,958 investments for France, with a total of 96,690 jobs created and reported. The difference in terms of number of projects between the two databases seems mainly explained by the better reporting of small projects in the Bilan France. After completing the missing value using my methodology, I obtain a total of 179,191 jobs created. Difference in terms of methodology prevents an individual projects comparison. Also it is difficult to compare time periods directly, as E\&Y generally integrates investments in its data set more rapidly.

8. In practice, I will run five independent regressions-one for each function-in order to estimate country fixed effect for each type of investment. In fact, each activity could be affected differently by country characteristics; therefore, different country fixed effects must be estimated.

9. We consider the service function of a manufacturing sector, for example, the headquarters of an automotive company, but not any project of the service sectors, for example, the headquarters of a financial sector firm.

10. Two headquarters, five R\&D centers, twenty-two production plants, one logistics center, and seven sales and marketing offices.

11. A site extended in 2000 with no creation reported during the period 1997-2002 would be considered as anterior to 1997. It is important not to consider the same project several times. For example, a production plant created in 1999 and extended in 2001 is considered as existing since 1999. 
12. I count as just one all the projects in a specific function and in a particular city (the most detailed geographical level) for each parent company. For example, if a firm decides to locate two production plants in the same city, I consider this investment once. This allows establishing an investment history at city level and avoids counting the same project several times.

13. In the case of a joint venture, I consider an investment for each parent company engaged in this investment (recall that I consider only joint ventures that lead to an extension or a new establishment creation).

14. As noted in the econometric model section, unobserved characteristics of the choosers might affect the IIA assumption. One way to relax this assumption is to introduce individual random effects and estimate a mixed logit model (Brownstone and Train 1999). Using the same data set, Defever (2006) provides estimation implementing a mixed logit. Introducing country variables instead of country fixed effects produces the same result.

15. As I implement five independent regressions with country fixed effects, I took into account the fact that different types of activities can react differently to country characteristics. It is also possible that some country characteristics can encourage not only the location of two functions simultaneously but also the co-location itself. For example, a country with a good communication sector can encourage co-location independent of the interaction between functions and country characteristics. To explore the robustness of these results, I ran a unique regression with all investments independent of the type of activity. Because each type of activity can react differently to country characteristics, I have introduced five times twenty-three country fixed effects, so I still have specific country fixed effects for each function. These results stay mainly stable. In order to study the hypothesis that some country characteristics could be at the origin of the co-location of activities, I introduced another set of country fixed effects shared by all investments, independent of their type of function. This fixed effects should integrate country characteristics, which could influence the co-location of activities, but my results stay mainly stable with the change of specification.

16. Although it is not the main purpose of this chapter, policy variables such as taxes could be interesting to study. Using the same setup as Defever (2006), I included a tax variable. I have been able to collect corporation tax data for all twenty-three countries of the enlarged Europe. Even so, it is important to notice that to my knowledge, no data set computes comparable data for all these countries, and so it is not clear if they are fully comparable. When implemented, this variable had a significant (at 10 percent) and positive coefficient (inverse sign of our expectation) in the case of headquarters location choice, negative (at 10 percent) in the case of sales and marketing, and not significant for the other functions. My co-location variables were mainly stable with the introduction of this variable.

17. In fact, my co-location variables could indicate that there is no previous investment by a firm, when in reality there is previous establishment realized before 1997 and not extended during the period 1997-2002. In this case, my estimate coefficients could be biased and mainly contain information about firms that are busy expanding.

\section{References}

Barba Navaretti, G., and A. J. Venables. (2004). Multinational Firms in the World Economy. Princeton, N.J.: Princeton University Press. 
Brownstone, D., and K. Train. (1999). Forecasting New Product Penetration with Flexible Substitution Patterns. Journal of Econometrics 89(1), 109-129.

Chung, W., and J. Song. (2004). Sequential Investment, Firm Motives and Agglomeration of Japanese Electronics Firms in the US. Journal of Economics and Management 13(3), 539560 .

Defever, F. (2006). Functional Fragmentation and the Location of Multinational Firms in the Enlarged Europe. Regional Science and Urban Economics 36(5), 658-677.

Devereux, M. P., and R. Griffith. (1998). Taxes and the Location of Production: Evidence from a Panel of US Multinationals. Journal of Public Economics 68, 335-367.

Hatem, F., and F. Defever. (2003). La france face aux nouvelles tendances de l'investissement international en europe. Accomex 54, 36-44.

Head, K., J. Ries, and D. Swenson. (1995). Agglomeration Benefits and Location Choice: Evidence from Japanese Manufacturing Investment in the United States. Journal of International Economics 38, 223-257.

Head, K., J. Ries, and D. Swenson. (1999). Attracting Foreign Manufacturing: Investment Promotion and Agglomeration. Regional Science and Urban Economics 29, 197-218.

Krugman, P. (1995). Growing World Trade: Causes and Consequences. Brookings Papers on Economic Activity 1, 327-342.

Markusen, J. R. (2005). Modeling the Offshoring of White-Collar Services: From Comparative Advantage to the New Theories of Trade and FDI. Working paper no. 11827, National Bureau of Economic Research, Cambridge, Mass.

McFadden, D. (1984). Handbook of Econometrics, vol. 2. Amsterdam: Elsevier/NorthHolland.

Smith, D., and R. Florida. (1994). Agglomeration and Industry Location: An Econometric Analysis of Japanese-Affiliated Manufacturing Establishments in Automotive-Related Industries. Journal of Urban Economics 36, 23-41.

Train, K. (2003). Discrete Choice Methods with Simulation. Cambridge: Cambridge University Press.

World Investment Report. (2001). Annual Report: Promoting Linkages. New York: UNCTAD. 
